\title{
Studies on pig diets containing different amounts of linoleic acid
}

\author{
BY W. M. F. LEAT* \\ School of Agriculture, University of Cambridge \\ (Received I February 1962-Revised 21 May 1962)
}

Since the deficiency syndrome caused by lack of essential fatty acids (EFA) was first described by Burr \& Burr (1929) many species besides rats have been shown to require EFA, but evidence about the pig is rather sparse and conflicting. Ellis \& Isbell (I926) and Ellis \& Zeller (1930) reared pigs on diets containing only $0.5 \%$ 'ether extract', but observed none of the classical signs of EFA deficiency. Witz \& Beeson (195 I) studied diets containing $0.06 \%$ fat and noted that their pigs had a reduced rate of weight increase and suffered from dermatitis, necrosis of the skin and loss of hair. Hill, Warmanen, Hayes \& Holman (1957) found a high mortality in miniature pigs reared on diets low in fat, but observed no skin lesions. Deuel (I957) considered the pig to represent a species relatively refractory to EFA deficiency.

In EFA deficiency, the content of trienoic acid in tissue lipids rises(Nunn \& SmedleyMacLean, 1938). This observation has been confirmed in the rat (Rieckehoff, Holman \& Burr, r949), and has been noted also in the dog (Wiese, Hansen \& Baugham, I957), the chick (Reiser, 195 I) and the pig (Leat, I96I $a$ ), but not in the guinea-pig (Reid \& Martin, I959). Holman (1960) has used this metabolic lesion as a basis for estimating the degree of EFA deficiency and has suggested that the ratio, trienoic:tetraenoic acids can be an index of EFA requirement in rats. This trienoic acid formed in EFA deficiency has been identified as an eicosatrienoic acid derived from oleic acid (Mead \& Slaton, I956; Fulco \& Mead, r959).

The experiments reported below arose from observations on pigs reared on diets low in tocopherol and EFA. The object was to investigate the fatty acid composition of pigs reared on diets containing various amounts of linoleic acid, and also to test whether the trienoic:tetraenoic acid ratio was as suitable for estimating EFA status in the pig as in the rat. Recently Hill, Warmanen, Silbernick \& Holman (I96I) have shown it to be so for miniature pigs.

Preliminary accounts of the work here reported have been published (Leat, I959, г96 ( $a, b)$.

\section{EXPER IMENTAL}

\section{Diet and animals}

Expts I and 2 were with pigs kept on diets low in tocopherol and EFA, but only information relevant to EFA requirement will be quoted here. Other experimental details have already been published (Leat, I96 I $a$ ).

\footnotetext{
* Present address: Institute of Animal Physiology, Babraham, Cambridge.
} 
The unsaturated fatty acid content of the dietary components and the composition of the diet used in Expt 3 are shown in Table $\mathrm{I}$.

Expt $\mathrm{I}$. Eight Large White $\times$ Essex piglets were weaned at $\mathrm{io} \mathrm{lb}$ and brought to $200 \mathrm{lb}$ live weight, four on a diet containing $0.07 \%$ and four on a diet containing $0.5 \%$ of the calories as linoleic acid. For the last 5 weeks of the experiment the linoleic acid content of the diet of one pig on the low-fat diet was raised so that it supplied $0.5 \%$ of the calories.

Table I. Percentage composition of diet used in Expt $3(A)$, and unsaturated fatty acids in individual components $(B)$

(B)

\begin{tabular}{|c|c|c|c|c|c|}
\hline \multirow[b]{3}{*}{ Ingredient } & \multirow{2}{*}{\multicolumn{2}{|c|}{$(A)$}} & \multicolumn{3}{|c|}{$(B)$} \\
\hline & & & \multirow{2}{*}{$\begin{array}{c}\text { Ether } \\
\text { extract } \\
(\%)\end{array}$} & \multirow{2}{*}{$\begin{array}{l}\text { Diethenoid } \\
\text { fatty acids } \\
\text { as \% of } \\
\text { ether } \\
\text { extract }\end{array}$} & \multirow{2}{*}{$\begin{array}{l}\text { Triethenoi } \\
\text { fatty acids } \\
\text { as \% of } \\
\text { ether } \\
\text { extract }\end{array}$} \\
\hline & $\mathrm{Up}$ to $\mathrm{roo} \mathrm{lb}$ & $100-200 \mathrm{lb}$ & & & \\
\hline Cassava & $42 \cdot 5$ & $52 \cdot 5$ & 0.39 & $8 \cdot 9$ & $2 \cdot 5$ \\
\hline Extracted palm-kernel cake & $10 \cdot 0$ & $15^{\circ} \mathrm{O}$ & $I \cdot 40$ & $1 \cdot 9$ & o \\
\hline Dried brewer's yeast & $5 \cdot 0$ & $5 \cdot 0$ & 0.51 & $1 \cdot 5$ & o \\
\hline Dried skim milk & $40 \cdot 0$ & $25^{\circ} 0$ & $1 \cdot 52$ & $x \cdot 7$ & o \\
\hline White-fish meal & - & $-\infty$ & 3.74 & 0.5 & $\circ$ \\
\hline Minerals & $2 \cdot 5$ & $2 \cdot 5$ & - & - & - \\
\hline Olive oil & * & * & $100 \cdot 0$ & $9 \cdot 6$ & $0 \cdot 6$ \\
\hline
\end{tabular}

Table 2. Plan of Expt 3, showing initial and final weights of pigs, treatment, and dietary content of 'linoleic acid'

Pig no.

Weaning weight (lb)

Slaughter weight (lb)

Days on diet

Olive oil in diet $(\%)$

Percentage of total dietary calories supplied by 'linoleic acid'

$\begin{array}{rrr}1 & 2 & 3 \\ 12 & 8 & 9 \\ 206 & 210 & 213 \\ 154 & 159 & 154 \\ 0 & 0 & I \\ 0.07 & 0.07 & 0.28\end{array}$

\begin{tabular}{rrr}
4 & 5 & \multicolumn{1}{c}{6} \\
10 & 11 & 12 \\
208 & 210 & 208 \\
159 & 154 & 159 \\
2 & 4 & 16 \\
0.50 & 0.93 & 3.50
\end{tabular}

Expt 2. Ten Large White $\times$ Essex piglets were weaned at $10 \mathrm{lb}$ and brought to $200 \mathrm{lb}$ live weight on a diet containing $0.18 \%$ of the calories as linoleic acid. Blood samples were taken at the half-way stage and again at slaughter.

Expt 3. Six Large White $\times$ Essex gilts from the same litter were weaned at 17 days and numbered $\mathrm{I}-6$. The pigs were penned individually and fed as recorded in Table 2 .

To ensure that Expt 3 was comparable with the other two experiments, olive oil was chosen as a source of linoleic acid and replaced an isocaloric weight of cassava in the diet. A supplement of $\alpha$-tocopheryl succinate $(25 \mathrm{mg} / \mathrm{lb}$ diet) was also given.

Blood samples were taken at 4 weeks of age and then at monthly intervals until slaughter. 


\section{Collection of blood and sampling of tissues}

Collection of blood. Samples were obtained from the ear vein, allowed to clot and centrifuged to obtain the serum.

Outer back-fat samples. Samples weighing $5 \mathrm{~g}$ were finely chopped and extracted with freshly distilled diethyl ether for $3 \mathrm{~h}$ in a Soxhlet apparatus. To minimize oxidation, $100 \mathrm{mg}$ of hydroquinone were added to the receiving flask and the extraction process was carried out in subdued light. The ether was distilled off under a stream of nitrogen, and the resulting lipid was dissolved in light petroleum (b.p. $60^{\circ}-80^{\circ}$ ), and the solution was stored at $0^{\circ}$.

Liver and heart samples. Samples weighing $20 \mathrm{~g}$, free from adhering fat, were cut into small pieces with scissors and then ground up thoroughly in a pestle and mortar with sand, and transferred to a beaker. To extract the lipid the tissue was boiled for 2 min with $40 \mathrm{ml}$ ethanol and the extract filtered off, the process being repeated with the residue once with another $40 \mathrm{ml}$ ethanol and twice with $40 \mathrm{ml}$ diethyl ether. The extracts were bulked and taken almost to dryness under a stream of nitrogen. The lipid was then dissolved in $25 \mathrm{ml}$ light petroleum (b.p. $60^{\circ}-80^{\circ}$ ), and the solution was filtered and stored at $0^{\circ}$.

\section{Analytical methods}

Solvents. Solvents were purified as previously described (Leat, I961 $a$ ).

Chemical methods. The fatty acids of the tissue lipids were isolated by the method of Böttcher, Woodford, Boelsma-van Houte \& van Gent (1959). The fatty acids were analysed by alkali isomerization (Herb \& Riemenschneider, 1953) and those of depot fat also by gas-liquid chromatography.

The fatty acids of the blood serum were extracted and determined by the method of Pikaar \& Nijhof (1958) and also by gas-liquid chromatography.

The methyl esters of the fatty acids for analysis by gas-liquid chromatography were prepared by refluxing the fatty acids for $\mathrm{I} h$ with anhydrous methanol containing $2 \%(\mathrm{v} / \mathrm{v})$ sulphuric acid. Hydroquinone ( $\mathrm{rmg} / \mathrm{ro} \mathrm{mg}$ fatty acid) was added to all refluxing solutions.

The methyl esters were separated at $190^{\circ}$ on a column containing $10 \%$ polyethylene glycol adipate on 100-I 20 mesh Celite by means of a Pye Argon Chromatograph with a ${ }^{90}$ Sr detector (W. G. Pye \& Co. Ltd, Cambridge).

\section{RESULT S}

\section{Expt I}

The pigs receiving $0.07 \%$ of the calories as linoleic acid had a pronounced scaliness of the skin, first noted after about $\mathrm{I} 3$ weeks on the diet (Pl. I $a$ ). The scaliness seemed to be confined to the dorsal surface and was most severe about the shoulders. The hair itself was dry and appeared to stand out from the skin at all angles. There was no loss or discoloration of the hair. In contrast, the pigs receiving $0.5 \%$ of the calories as linoleic acid had little or no flakiness of the skin. The hair lay close to the skin and had a sleek, well-groomed appearance (Pl. I $b$ ). 
There was no difference in rate of weight gain between the two groups, and at slaughter no abnormalities were noted in any of the carcassses or organs, except for a slight red rash along the backs of those pigs on the low-fat diet.

When the linoleic acid intake of one of the pigs on the low-fat diet was raised to supply $0.5 \%$ of the calories for the last 5 weeks of the experiment, this animal appeared to show some improvement in the condition of its skin whereas a control animal did not.

\section{Expt 2}

Weight gain was normal and the condition of the skin was considerably better than in the animals of the low-fat group in Expt I. The appearance of the skin was better in the animals penned in pairs than in those penned individually. The trienoic:tetraenoic acid ratios in the blood serum are shown in Table 3 .

Table 3. Expt 2. Ratio, trienoic:tetraenoic acid in serum at the half-way stage and at slaughter

\begin{tabular}{|c|c|c|c|c|c|c|c|c|c|c|}
\hline Pig no. & $\mathbf{I}$ & 2 & 3 & 4 & 5 & 6 & 7 & 8 & 9 & 10 \\
\hline Half-way stage & $2 \cdot 7$ & $2 \cdot 7$ & $2 \cdot 1$ & $2 \cdot 1$ & $3 \cdot 3$ & $1 \cdot 7$ & $3 \cdot 0$ & $2 \cdot 6$ & 4.4 & $3 \cdot 3$ \\
\hline At slaughter & $2 \cdot 2$ & $2 \cdot 6$ & $2 \cdot 1$ & 2.5 & $3 \cdot 2$ & $2 \cdot 2$ & 2.0 & $2 \cdot 3$ & $2 \cdot 8$ & 2.6 \\
\hline
\end{tabular}

Table 4. Expt 3. Unsaturated fatty acids of serum at slaughter, as determined by alkali isomerization and gas-liquid chromatography (for treatment see Table 2)

Acid

$$
\begin{aligned}
& \text { Diethenoid (\%) } \\
& \text { Triethenoid (\%) } \\
& \text { Tetraethenoid (\%) } \\
& \text { Pentaethenoid (\%) } \\
& \text { Total fatty acids (mg/ } \\
& \text { I0o ml serum) } \\
& \text { Cholesterol (mg/ } 100 \mathrm{ml} \\
& \text { serum) } \\
& \text { Linoleic (\%) } \\
& \text { Linolenic (\%) } \\
& \text { Eicosatrienoic (\%) } \\
& \text { Arachidonic (\%) }
\end{aligned}
$$

Pig no. I

Pig no. 2

Alkali isomerization

$6 \cdot 2$
$6 \cdot 8$
$3 \cdot 5$
0.8
190
101

$\quad$ G
9.12
0.68
6.00
2.56

$\begin{array}{rr}5.7 & 9.0 \\ 6.8 & 4.7 \\ 2.9 & 4.3 \\ 0.6 & 0.5 \\ 182 & 173 \\ & \\ 110 & 107\end{array}$

Gas-liquid chromatography

$\begin{array}{rrr}8.92 & 13.60 & 15.00 \\ 0.70 & 0.38 & 0.62 \\ 5.30 & 3.82 & 3.26 \\ 2.06 & 3.06 & 3.91\end{array}$

Pig no. 5 Pig no. 6

Pig no.

$\begin{array}{rrr}9 \cdot 9 & 12.5 & 16 \cdot 3 \\ 3.5 & 1.8 & 1.5 \\ 5.2 & 7.1 & 6.6 \\ 0.7 & 0.8 & 0.7 \\ 193 & 185 & 211 \\ 117 & 121 & 125\end{array}$

$\operatorname{Expt} 3$

All animals grew well, and there was no difference in rate of weight increase. The appearance of pigs nos. I and 2 was similar to that of the pigs fed on the low-fat diet in Expt $\mathrm{I}$, but the scaliness of the skin was not as severe. The condition improved as the percentage of oil in the diet increased, but the flakiness of the skin did not entirely disappear, even though pig no. 6 was receiving $16 \%$ olive oil in the diet and had obviously oily skin. At slaughter all organs appeared normal, and examination of the aortas revealed no lesions visible to the naked eye. The carcasses were accepted for human consumption.

The content of unsaturated fatty acids in serum is shown in Table 4 , and those in 
liver, heart and depot fat in Table 5. The relationship between dietary linoleate and the polyunsaturated fatty acids of various tissues is shown in Fig. $I$.

The variation of the ratio, trienoic:tetraenoic acids in serum with age is shown in Fig. 2, and the fatty acid composition of depot fat estimated by gas-liquid chromatography is recorded in Table 6.

Table 5. Expt 3. Unsaturated fatty acids of liver, heart and depot fats at slaughter (for treatment see Table 2)

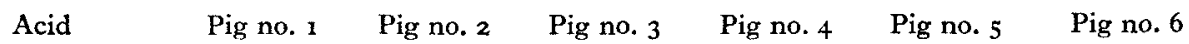

$\begin{array}{lr}\text { Diethenoid (\%) } & 2 \cdot 6 \\ \text { Triethenoid (\%) } & 6 \cdot 8 \\ \text { Tetraethenoid (\%) } & 9 \cdot 2 \\ \text { Pentaethenoid (\%) } & 2 \cdot 7 \\ \text { Hexaethenoid (\%) } & 1 \cdot 5 \\ \text { Iodine value } & 108\end{array}$

Diethenoid (\%)

Triethenoid (\%)

Tetraethenoid (\%)

Iodine value

Monoethenoid (\%)

(by difference)

Diethenoid (\%)

Triethenoid (\%)

Tetraethenoid (\%)

Pentaethenoid (\%)

Hexaethenoid (\%)

Iodine value

Diethenoid (\%)

Triethenoid (\%)

Tetraethenoid (\%)

Iodine value

Monoethenoid (\%)

(by difference)

\section{Liver}

$5 \cdot 1$
$5 \cdot 3$
$13 \cdot 3$
$2 \cdot 8$
$2 \cdot 1$

113

Outer back fat

$\begin{array}{rr}0.6 & 1 \\ 0.2 & 0 \\ 0.1 & 0 \\ 52.2 & 56 \\ 55.9 & 58\end{array}$

$55 \cdot 9$

Heart

$4 \cdot 2$
$6 \cdot 8$
$10 \cdot 5$
$2 \cdot 7$
$1 \cdot 4$
98

$\begin{array}{rr}8 \cdot 5 & 13 \cdot 6 \\ 4.8 & 7 \cdot 0 \\ 4.6 & 6 \cdot 5 \\ 1 \cdot 5 & 1 \cdot 2 \\ 0.2 & 0.1 \\ - & 93\end{array}$

$5 \cdot 3$
$3 \cdot 5$
$15 \cdot 0$
$2 \cdot 6$
$1 \cdot 8$
117

$r \cdot 9$
$0 \cdot 3$
$0 \cdot 1$
$58 \cdot 6$
$60 \cdot 0$

$\begin{array}{rr}3 \cdot 2 & 7 \cdot 1 \\ 0 \cdot 4 & 0.5 \\ 0.3 & 0.2 \\ 59 \cdot 8 & 76 \cdot 8 \\ 57 \cdot 8 & 68 \cdot 5\end{array}$

$$
\begin{array}{r}
0.4 \\
0.2 \\
0.1 \\
45.0 \\
48.2
\end{array}
$$

Perinephric fat

$22 \cdot 9$
$3 \cdot 1$
$13 \cdot 5$
$1 \cdot 7$
0.2
108

$22 \cdot 3$
$0 \cdot 5$
$13 \cdot 3$
$r \cdot 6$
$0 \cdot 2$
108

24.7

0.0

14.7

I.3

0.3

I06

$\begin{array}{rrrrr}0.3 & 1.0 & 1.8 & 2.5 & 6.7 \\ 0.1 & 0.2 & 0.4 & 0.3 & 0.6 \\ 0.1 & 0.1 & 0.2 & 0.2 & 0.2 \\ 43.0 & 47.5 & 49.9 & 50.3 & 70.7 \\ 46.5 & 49.9 & 49.9 & 49 \cdot 2 & 62.8\end{array}$

\section{DISCUSSION}

\section{Rate of weight gain and skin signs}

Witz \& Beeson (195 I) described signs of EFA deficiency in pigs reared for $5^{6-}$ 77 days on diets containing 0.12 or $0.06 \%$ fat. The initial live weight of the pigs was $35-48 \mathrm{lb}$ and the final weight about $128 \mathrm{lb}$. The animals receiving $0.12 \%$ fat grew as well as the controls on $5 \%$ lard, but those receiving $0.06 \%$ fat had a reduced rate of weight gain, which tended to plateau after $6_{3}$ days. In my experiments the basal lowfat diet contained about $\mathrm{I} \cdot \mathbf{2} \%$ fat, but it was highly saturated, so that the diet contained only $0.07 \%$ of the calories as linoleic acid. My pigs were weaned earlier (10 lb live weight) and slaughtered later (200 lb live weight) than those of Witz \& Beeson, but showed throughout excellent growth in no way different from that of pigs receiving 


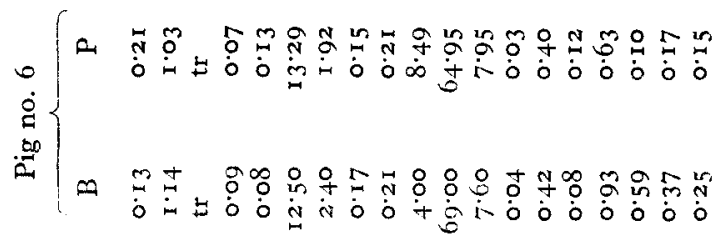

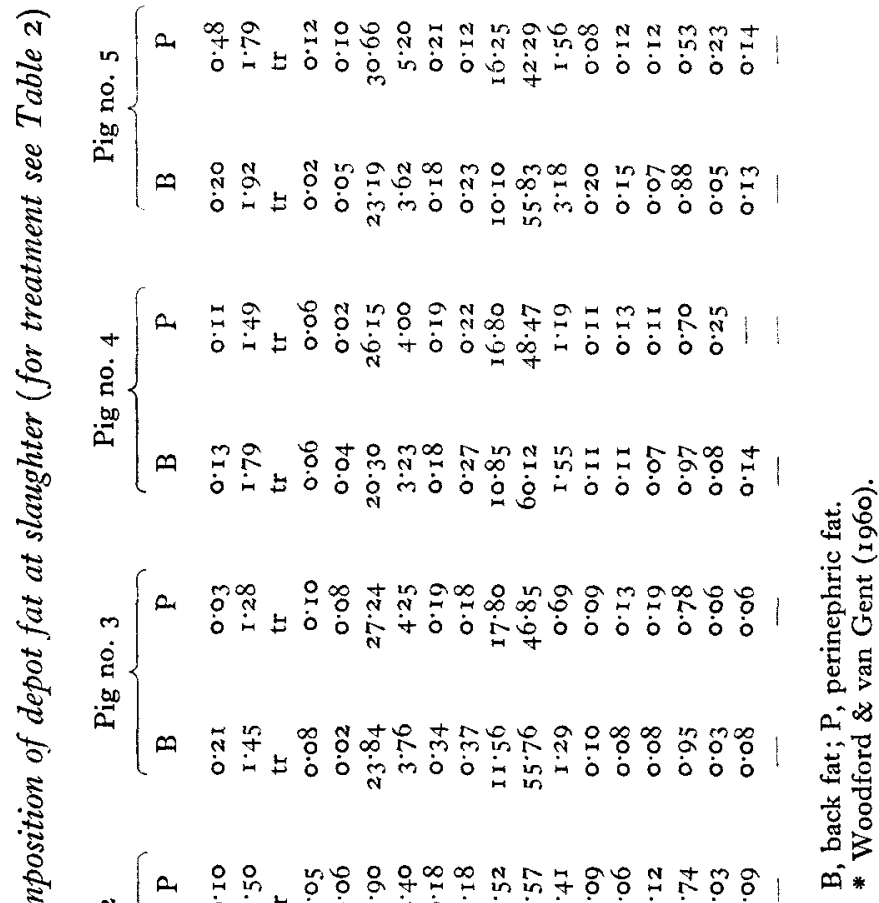

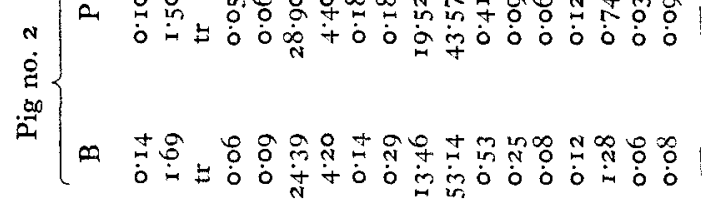

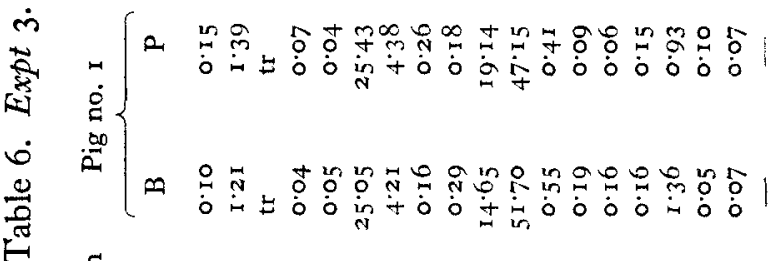

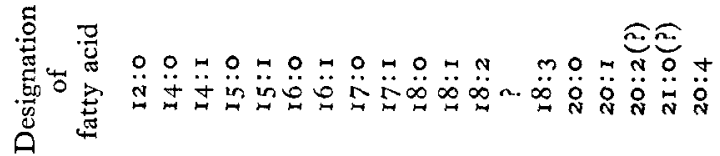

窇尊 
additional linoleate. At slaughter, however, the animals were only half grown, and it is possible that a difference in growth rate might have become apparent before maturity was reached. The deficiency signs noted here were similar in some respects to those reported by Witz \& Beeson, but less severe. No details of the pre-experimental diet used were published by Witz \& Beeson, so that it was not possible to estimate what

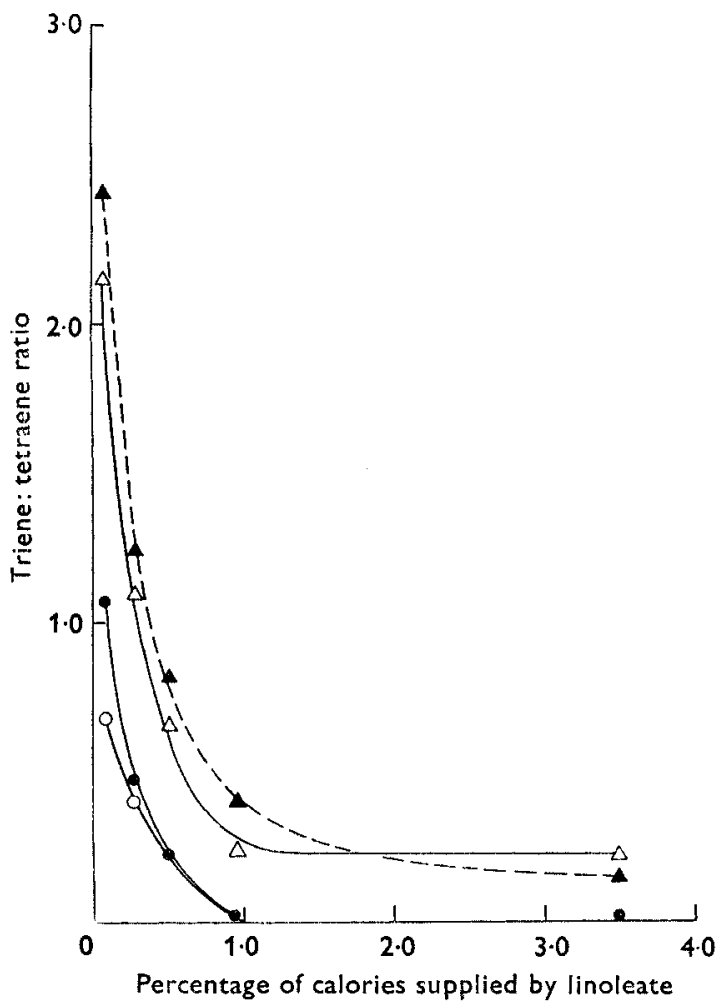

Fig. I

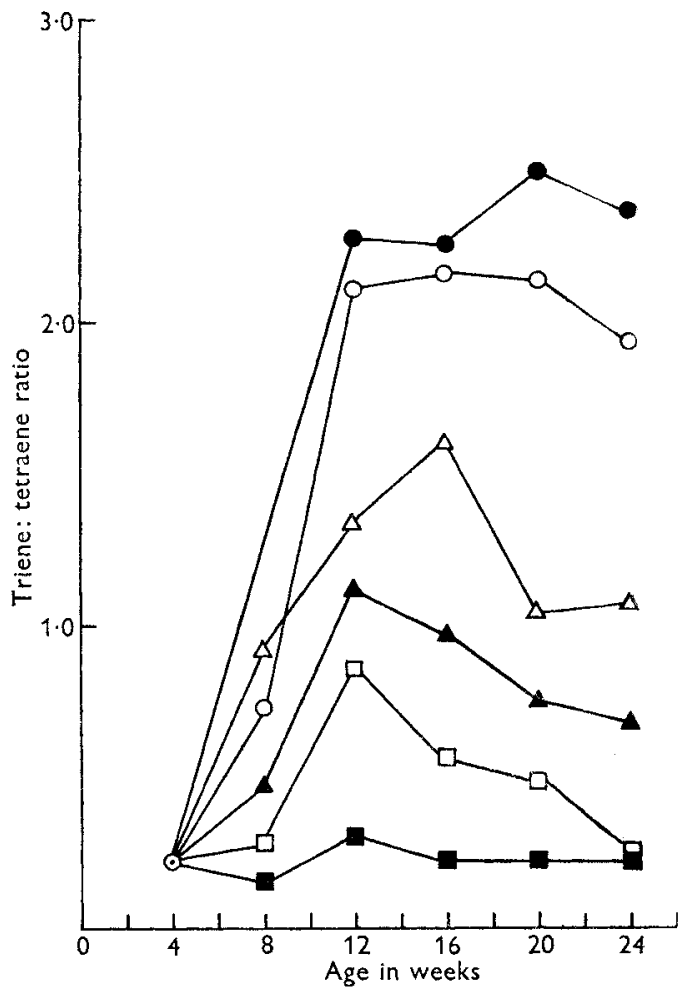

Fig. 2

Fig. I. Expt 3. Relationship between dietary linoleate and the trienoic: tetraenoic acid ratio in various tissues of pigs at $200 \mathrm{lb}$ live weight. $0-0$, liver; $\bullet-\bullet$, heart; $\Delta \rightarrow \Delta$, serum; $\Delta-\mathbf{\Delta}$, eicosatrienoic: arachidonic acid ratio in serum.

Fig. 2. Expt 3. Relationship for six individual pigs between age and the trienoic:tetraenoic acid ratio in serum, when the percentage of calories supplied by linoleate was: $0 \longrightarrow 0$ and $\bullet, 0.07 \% ; \Delta-\Delta, 0.28 \% ; \Delta-\Delta, 0.50 \% ; \square-\square, 0.93 \% ;-3.50 \%$.

storage of linoleic acid could have occurred in their pigs before weaning. The differences between the results in the two experiments are probably best explained by the presence of sufficient linoleic acid in the diet used by me, but not in that of Witz \& Beeson, to satisfy the requirement of the pig for growth.

Hill et al. (1957) and Hill et al. (1961) noted no skin abnormalities in miniature pigs reared on diets deficient in fat, although the growth rate was affected. Their lowest linoleate supplement, providing $0.23 \%$ of the calories, produced a marked increase in rate of weight increase over the controls receiving $0.02 \%$ of their calories 
as linoleate. There was no group, however, comparable to my animals receiving the lowest level of linoleate ( $0.07 \%$ of the calories).

Skin lesions are not a good criterion of EFA status, being variable and non-specific. In Expt 3, for example, although two pigs were receiving substantially the same basal diet, low in fat, as used in Expt I, the dermatitis noted was much less severe. Also, the pig receiving $16 \%$ olive oil, although considerably improved in appearance, was not free from flakiness of the skin. Whether the animals are penned individually or in groups may be of some importance. In Expt 2, for instance, the skin condition was noticeably better in those pigs penned in pairs than in those penned individually. Keeping animals in close proximity with each other may prevent dermatitis becoming apparent as a result merely of physical contact.

\section{Unsaturated fatty acids of serum, liver and heart}

A more specific criterion of EFA deficiency is the rise in the content of eicosatrienoic acid in tissue lipids. Holman (1960) has suggested that the ratio, trienoic: tetraenoic acids is a good index of EFA status and has shown that in rats a ratio higher than 0.4 indicates that the minimum dietary requirement of linoleate has not been met. In Expt 2 the mean ratio at the half-way stage was $2 \cdot 79$ and at slaughter $2 \cdot 45$. It would seem therefore that, if this ratio is valid for pig nutrition, a dietary level of linoleate providing $0.18 \%$ of the calories is insufficient to prevent this metabolic lesion.

In Fig. I the trienoic:tetraenoic ratios of various tissues from pigs in Expt 3 are plotted against dietary linoleate. On the hyperbolic curve obtained, the leg for the high ratio represents an insufficiency of linoleate, and the leg for the low ratio represents adequate dietary linoleate. The shape of the curve is the same for serum, liver and heart, although the serum curve is displaced upwards because of the lower content of tetraenoic acid. The curve for serum trienoic:tetraenoic acid ratios obtained by alkali isomerization is similar to that for eicosatrienoic: arachidonic acid ratios obtained by gas-liquid chromatography, indicating that values obtained by the less specific method are valid.

In all curves plotted from results obtained by alkali isomerization, the greatest change in the shape occurs at about $\mathrm{I} \%$ of the calories, which would indicate that at least I \% of the calories must be supplied as linoleate to prevent the metabolic lesion from developing. This suggestion is supported by the fact that the curves flatten out sharply above $\mathrm{I} \%$, and there is little difference between the trienoic:tetraenoic ratio at $\mathrm{r} \%$ and at $3.5 \%$ of the calories. However, the change in the slope of the curve obtained from gas-liquid chromatography values is less sharp and does not flatten out before the values for about $2 \%$ of the calories. Also, the absolute values for trienoic acid and eicosatrienoic acid were lower in tissues of the pig receiving $3.5 \%$ of its calories as linoleate than in those of the one receiving $0.95 \%$ (Tables 4 and 5 ). These findings indicate that the requirement of the pig for linoleic acid is, in terms of calorie supply, somewhat higher than $\mathrm{I} \%$ but probably less than $2 \%$.

The fatty acid values for serum obtained by alkali isomerization were in fair agreement with those obtained by gas-liquid chromatography. The trienoic acid value 
agreed well with the sum of the values for eicosatrienoic acid and linolenic acid, but the value for dienoic acid was about $50 \%$ lower than that for linoleic acid, and that for tetraenoic acid about $40 \%$ higher than for arachidonic acid. However, in the alkali isomerization method constants used for linolenic acid may not be applicable for eicosatrienoic acid.

\section{Trienoic: tetraenoic acid ratio of serum in relation to age}

From Fig. 2 it will be seen that the triene:tetraene ratio at 24 weeks is not a true reflection of the EFA status throughout the experiment. Thus, at the end of the experiment the ratios for pigs nos. 5 and 6 were almost the same, whereas at 12 weeks they differed considerably. In all animals, except pig no. 6 , the ratio reached a peak at about I2-16 weeks and then either reached a plateau or fell, the maximum value being related to the dietary linoleate. It would therefore appear that the requirement of the pig for EFA is not constant throughout growth, but is maximal in the first I 6 weeks of life: I \% of the calories as linoleate is sufficient to prevent the metabolic lesion from developing when the first 24 weeks of life are examined in entirety but is not sufficient over the first I6 weeks' period. Except for pigs nos. I and 2, the level of dietary linoleate was sufficient to cause a reduction in the triene: tetraene ratio after I 2 weeks. In pigs nos. I and 2 the dietary level was sufficient only to cause the ratio to reach a plateau. When the triene:tetraene ratio is used to assess EFA status, it is therefore important to take the age of the animal into account. A possible explanation for the decreased requirement of the pig for EFA after 12-16 weeks is that after approximately $100 \mathrm{lb}$ live weight the pig deposits proportionately more fat and less muscle than it does up to roo $\mathrm{lb}$. Arachidonic and eicosatrienoic acids are confined mainly to the phospholipids (Leat, unpublished results), of which the content is greater in muscle than in adipose tissue.

\section{Fatty acid content of depot fat}

The rise in trienoic acid content noted in the lipids of serum, liver and heart of pigs in Expt 3 was not found in samples of depot fat. Increasing the level of olive oil in the diet caused a noticeable rise in iodine value and dienoic acid content of depot fat, but only slight increases in the levels of trienoic and tetraenoic acids. The perinephric fat was more saturated than back fat, with a lower iodine value.

Gas-liquid chromatographic analysis confirmed these findings on alkali isomerization. There was a complete absence of eicosatrienoic acid from both back fat and perinephric fat, and the small amount of trienoic acid detected by alkali isomerization could be accounted for as linolenic acid. Arachidonic acid was absent from all samples except that from pig no. 6 , which contained $0.25 \%$ in back fat and $0.15 \%$ in perinephric fat. The content of linoleic acid agreed well with values for dienoic acid obtained by alkali isomerization. Perinephric fat was more saturated than back fat, and contained more palmitic and stearic acids and less oleic and linoleic acids. Increasing the dietary level of olive oil caused a rise in the content of oleic and linoleic acids at the expense of palmitic, palmitoleic and stearic acids. 
Fatty acids containing sixteen and eighteen carbon atoms accounted for $95 \%$ of the fatty acids of adipose tissue. Less than $2 \%$ consisted of fatty acids containing more than eighteen carbon atoms. The minor fatty acids were lauric, myristic, myristoleic and odd-numbered fatty acids containing fifteen and seventeen carbon atoms.

These results should be compared with those of Kingsbury, Paul, Crossley \& Morgan (196r) for human fat, who found that the trienoic: tetraenoic ratio, as determined by alkali isomerization, was higher in the body fat of atheromatous than in that of normal human subjects. These authors tentatively suggested that it indicated an insufficiency of EFA. The results of my experiments on acute EFA deficiency in pigs do not support this suggestion. Although a trienoic acid was detected in depot fat by alkali isomerization, it represented not the eicosatrienoic acid synthesized in EFA deficiency, but probably dietary linolenic acid.

\section{SUMMARY}

I. The essential fatty acid (EFA) requirement of the pig has been investigated by rearing pigs from to to $200 \mathrm{lb}$ live weight on diets containing various amounts of linoleic acid given as olive oil.

2. Linoleate was included in the diet in amounts to supply from $0.07 \%$ to $3.50 \%$ of the calories, but no difference in growth rate or efficiency of food conversion was noted, although the condition of the skin was affected.

3. By using the ratio, trienoic: tetraenoic acids as an index of EFA status, it has been shown that up to $200 \mathrm{lb}$ live weight the pig requires about $\mathrm{x} \%$ of its calories as linoleic acid.

4. The requirement of the pig for linoleic acid was found to vary with age and was maximal up to $12-16$ weeks of age, when it began to decline.

5. Of the fatty acids from depot fat, $95 \%$ consisted of acids containing sixteen or eighteen carbon atoms, and only $2 \%$ had longer chains. Odd-numbered fatty acids containing fifteen or seventeen carbon atoms were detected. The eicosatrienoic acid found in the tissue lipids from animals deficient in linoleic acid was absent from depot fat. Arachidonic acid was either absent or present in very small amounts.

I thank Mr R. D. Willis and Mr V. H. Thurlbourn for looking after the experimental animals and Dr G. A. Gresham, Department of Pathology, University of Cambridge, for examining the carcasses at slaughter.

\section{REFERENCES}

Böttcher, C. J. F., Woodford, F. P., Boelsma-van Houte, E. \& van Gent, C. M. (1959). Rec. Trav. chim. Pays-Bas, 78, 794.

Burr, G. O. \& Burr, M. M. (1929). F. biol. Chem. 82, 345.

Deuel, H. J. Jr (1957). The Lipids. Vol. 3. New York: Interscience Publishers Inc.

Ellis, N. R. \& Isbell, H. S. (1926). F. biol. Chem. 69, 2 I9.

Ellis, N. R. \& Zeller, J. H. (1930). F. biol. Chem. 89, I85.

Fulco, A. J. \& Mead, J. F. (1959). F. biol. Chem. 234, I4I r.

Herb, S. F. \& Riemenschneider, R. W. (1953). Analyt. Chem. 25, 953.

Hill, E. G., Warmanen, E. L., Hayes, H. \& Holman, R. T. (r957). Proc. Soc, exp. Biol., N.Y., $95,274$. 
British Fournal of Nutrition, liol. I6, No. 4

Plate I
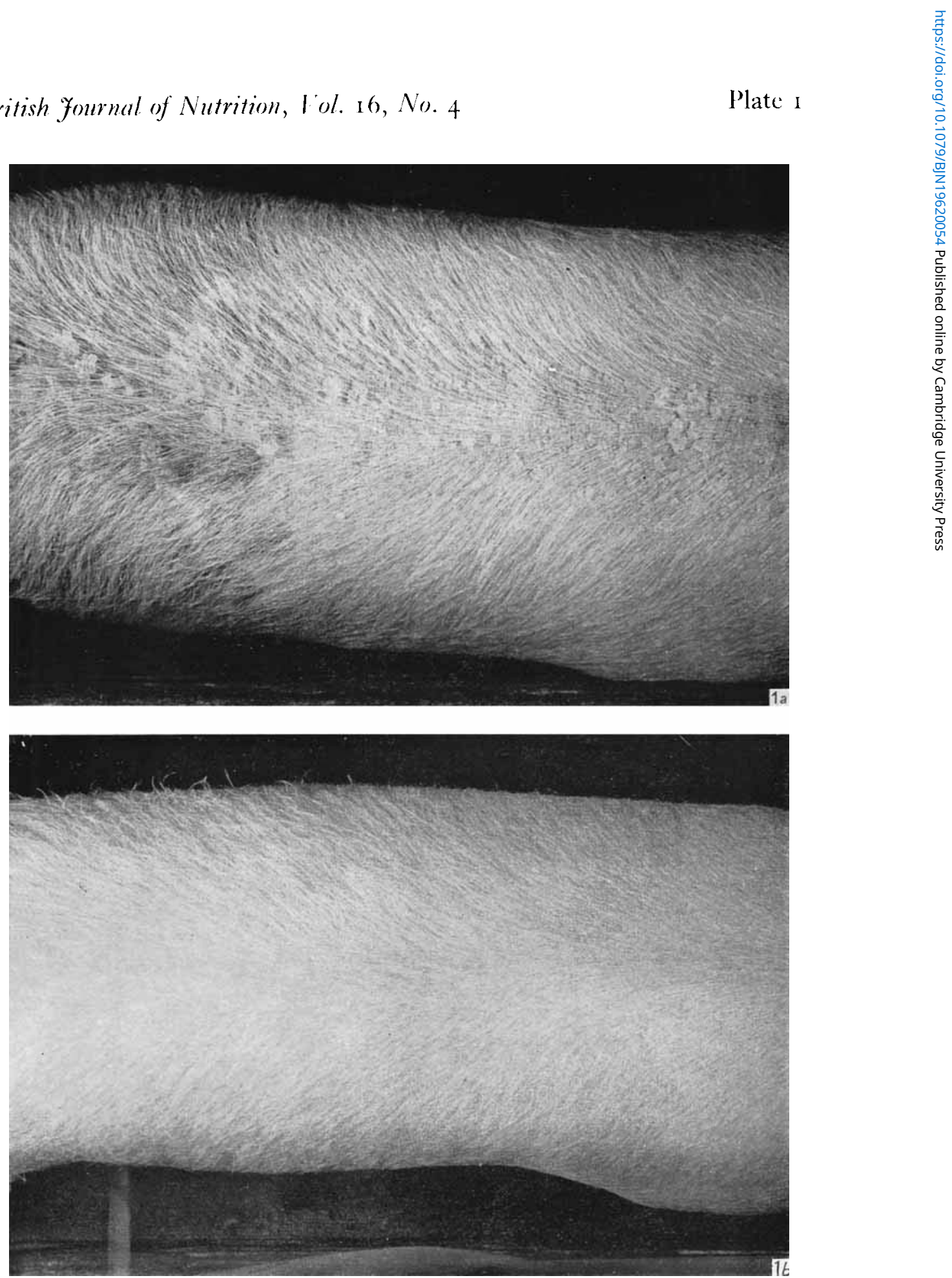

W. M. F. I.EA'T

(Facing p. 560) 
Hill, E. G., Warmanen, E. L., Silbernick, C. L. \& Holman, R. T. (1961). F. Nutr. 74, 335.

Holman, R. T. (1960). J. Nutr. 70, 405.

Kingsbury, K. J., Paul, S., Crossley, A. \& Morgan, D. M. (1961). Biochem. F. 78, 541.

Leat, W. M. F. (1959). Proc. Nutr. Soc. 18, xxxi.

Leat, W. M. F. (196ra). Brit. F. Nutr. 15, 259.

Leat, W. M. F. (196r $b$ ). Proc. Nutr. Soc. 20, xvi.

Mead, J. F. \& Slaton, W. H. Jr. (r956). F. biol. Chem. 219, 705.

Nunn, L. C. A. \& Smedley-MacLean, I. (1938). Biochem. F. 32, 2 r 78.

Pikaar, N. A. \& Nijhof, J. (1958). Biochem. $7.70,52$.

Reid, M. E. \& Martin, M. G. (r959). F. Nutr. 67, 6r I.

Reiser, R. (195I). F. Nutr. 44, 159.

Rieckehoff, I. G., Holman, R. T. \& Burr, G. O. (r949). Arch. Biochent. 20, 33 I.

Wiese, H. F., Hansen, A. E. \& Baugham, M. A. (1957). F. Nutr. 63, 523.

Witz, W. M. \& Beeson, W. M. (1951). F. Anim. Sci. ro, Ir2.

Woodford, F. P. \& van Gent, C. M. (1960). F. Lipid Res. 1, 188.

\section{EXPLANATION OF PLATE}

Plate I

View of dorsal surface of litter-mate pigs reared for 18 weeks on a diet containing (a) $0.07 \%$ and (b) $0.5 \%$ of the calories as linoleic acid. 